\title{
STUDIES IN SEARCH OF A SUITABLE EXPERIMENTAL INSECT MODEL FOR XENODIAGNOSIS OF HOSTS WITH CHAGAS' DISEASE \\ 3 - ON THE INTERACTION OF VECTOR SPECIES AND PARASITE STRAIN IN THE REACTION OF BUGS TO INFECTION BY TR YPANOSOMA CRUZI*
}

\author{
Alina Perlowagora-Szumlewicz** \\ Carlos Alberto Muller** \\ Carlos José de Carvalho Moreira**
}

\begin{abstract}
PERLOWAGORA-SZUMLEWICZ, A. et al. Studies in search of a suitable experimental insect model for xenodiagnosis of hosts with Chagas' disease. 3 - On the interaction of vector species and parasite strain in the reaction of bugs to infection by Trypanosoma cruzi. Rev. Saúde públ., S. Paulo, 22:390-400, 1988.
\end{abstract}

\begin{abstract}
The reaction of nine vector species of Chagas' disease to infection by seven different Trypanosoma cruzı strains; Berenice, Y, FL, CL, S. Felipe, Colombiana and Gávea, are examined and compared. On the basis of the insects' ability to establish and maintain the infection, vector species could be divided into two distinct groups which differ in their reaction to an acute infection by $T$. cruzi. While the proportion of positive bugs was found to be low in Triatoma infestans and Triatoma dimidiata it was high, ranging from $96.9 \%$ to $100 \%$ in the group of wild (Rhodnius neglectus, Triatoma rubrovaria) and essentially sylvatic vectors in process of adaptation to human dwellings, maintained under control following successful insecticidal elimination of Triatoma infestans (Panstrongylus megistus, Triatoma sordida and Triatoma pseudomaculata). An intermediate position is held by Triatoma brasiliensis and Rhodnius prolixus. This latter has been found to interchange between domestic and sylvatic environments. The most important finding is the strikingly good reaction between each species of the sylvatic bugs and practically all $T$. cruzl strains herein studied, thus indicating that the factors responsible for the excellent reaction of $P$.megistus to infection by $Y$ strain, as previously reported also come into operation in the reaction of the same vector species to acute infections by five of the remaining T.cruzi strains. Comparison of data reported by other investigators with those herein described form the basis of the discussion of Dipetalogaster maximus as regards its superiority as a xenodiagnostic agent.
\end{abstract}

UNITERMS: Trypanosomiasis, South American, diagnosis. Insect vectors, parasitology. Host-parasite, relations. Triatoma, parasitology. Panstrongylus, parasitology. Rhodnius, parasitology. Trypanosoma cruzl.

\section{INTRODUCTION}

Studies reported by the authors' 15,16 in 1982 and 1987 were beginning to uncover an extraordinary variety of vector species (Panstrongylus megistus, Rhodnius neglectus, Triatoma sordida, Triatoma pseudomaculata, Triatoma rubrovaria), which are being identified as successful xenodiagnostic agents.

All cited species, these considered, at the start of our laboratory colonies (1973), completely wild (Triatoma rubrovaria, Rhodnius neglectus), as well as those essentially sylvatic (Panstrongylus megistus, Triatoma sordida, Triatoma pseudomaculata) were superior to domiciliated Triatoma infestans, Triatoma dimidiata and Rhodnius prolixus in their reaction to $\mathrm{Y}$ strain of Trypanosoma cruzi.

The fact that P.megistus proved to be efficient in evaluating the infectivity potential of T.cruzi Y strain from acute ${ }^{14}$ as from chronic ${ }^{16}$ infections, seemed to us a major step in upgrading the efficiency of xenodiagnosis in field surveys***. However, the reaction of this vector to infection by other strains and/or isolates of $T$.cruzi raised questions which must be answered before the vector can be recommended for general use in experimental and natural infections. If all or some of the factors responsible for the excellent reaction of this vector to infection by $\mathrm{Y}$ strain are not operating in the reaction to infection by other strains, then the role of this vector as a

* $\quad$ Supported in part by the National Council of Research(CNPq). Proc. 403773/82 - PIDE V. Presented at the Annual Meeting on Basic Research in Chagas' Disease. Caxambu, Brazil, 1987.

** Laboratory of Vectors of Chagas' Disease. Department of Entomology. Oswaldo Cruz Institute Foundation (FIOCRUZ). Estr. da Covanca, 56, Jacarepaguá - 22700 - Rio de Janeiro, RJ - Brazil.

*** Unpublished experiments. 
xenodiagnostic agent would be of limited usefulness. Doubt would also be cast on the proposed general role of xenodiagnosis to detect infections by $T$.cruzi.

Since the initial guidelines for the study of xenodiagnosis in chronic infection by $Y$ strain were drawn up from findings in acute infections by this strain, the responsiveness of nine vector species to acute infections with seven different strains of T.cruzi were first studied. Results obtained are described. The animals which survived the acute infections formed the group of donors in xenodiagnosis of chronic infections, results of which will be reported in a forthcoming paper, the $4^{\text {th }}$ of this series.

\section{MATERIAL AND METHODS}

Protozoa: Six well known strains of T.cruzi and one "cruzi like" parasite isolated in 1977 by the senior author from naturally infected adults P.megistus collected in Gávea, Rio de Janeiro (Brazil), were used throughout the experiments.

T.cruzi Y strain isolated in S. Paulo (Brazil) in 1950 from a human infection was obtaíned from "Centro de Pesquisas René Rachou, Fundação Oswaldo Cruz (FIOCRUZ)", Belo Horizonte, MG, (Brazil) in 1974, and since then maintained in this laboratory by syringe passage.

Five other strains obtained in 1981 from the Dept. of Protozoology of "Instituto Oswaldo Cruz" of "FIOCRUZ" are: "Berenice" isolated in 1962 in "Belo Horizonte, MG", Brazil from the first human case of Chagas' disease; "São Felipe" isolated in "São Felipe, Bahia", (Brazil) in 1974; "Colombiana" isolated in 1962 in "Belo Horizonte, MG", "FL" and "CL" both isolated in 1963 from naturally infected bugs collected in "Rio Grande do Sul" (Brazil) "Gávea" a T.cruzi like parasite isolated from naturally infected adult P.megistus collected in "Gávea" area of "Rio de Janeiro" (Brazil) in 1977. There was difficulty in establishing an overt parasitemia in infected mice, which only occasionally showed one parasite in wet films of tail blood. Therefore this isolate has been maintained by feeding triatomid bugs on infected mice and inoculating their feaces or suspensions of the digestive tract ip into clean mice and guinea-pigs. These latter, in contrast to the former, developed long lasting parasitemia and like mice harbored the infection until death due to aging. Parasites found in Giemsa stained dried films of bug feaces or peripheral blood from guinea-pigs closely resemble the parasites of other T.cruzi strains.

Triatominae used: The domiciliated $T$. infestans, $T$. dimidiata and $R$. prolixus, T.sordida, T. pseudomaculata, T.brasiliensis, P.megistus, all essentially sylvatic but some like $T$. sordida and P.megistus in process of adaptation to human dwellings, in areas maintained under control following insecticidal elimination of T.infestans, as stated by Barreto $0^{4}$ and Forattini et al. ${ }^{5}$; T.rubrovaria and $R . n e g l e c t u s$ considered completely wild bugs although, the latter tends to colonize human homes in areas of intensive agricultural and cattle breeding activities as reported by Forattini et al. ${ }^{6}$ and by Silveira et al. ${ }^{17}$.

The origin and history of these bugs, reared under ambient conditions was described previously $(1982)^{13}$. Their life history parameters of major importance were reported by Perlowagora-Szumlewicz ${ }^{13,14}$.

Mammalian hosts: 42 guinea-pigs weighing from 300 to $350 \mathrm{gr}$ were divided in seven equal groups of six. All groups but one were inoculated ip with $0.2-0.3 \mathrm{ml}$ of infected mouse blood containing parasite numbers ranging from $10.2 \times 10^{4}$ to $10.8 \times 10^{4}$. Since mice inoculated with "Gávea" isolate only occasionally showed single parasites in the peripheral circulation, the infection has been induced through an inoculation of $1.0 \mathrm{ml}$. (10.1 $x 10^{4}$ parasites) of a saline suspension of the gut from infected P.megistus.

All guinea-pigs developed parasitemia which reached its peak between 21 and 36 days after inoculation of "Berenice", " $Y$ ", "FL" and "CL". In hosts harboring "São Felipe" or "Colombiana" it peaked within a period of 2668 days, in the group of guinea-pigs infected with the "Gávea" isolate it reached the highest level between the $35^{\text {th }}$ and $76^{\text {th }}$ day after inoculation.

Batches of bugs fed on infected animals: The scheme followed was essentially this described in 1982 with one major addition (Perlowagora-Szumlewicz \& Müller ${ }^{15}$ ). While previously the reaction of nine different vector species to infection by $Y$ strain was studied, the herein described experiments were extended to the responsiveness of the same nine vector species to experimental infections produced by seven different strains.

Groups of 54 clean fourth instar nymphs of each of the nine vector species, starved since their transition from the third stage, were fed in batches of nine specimens on groups of six guinea-pigs each, previously infected with one of the seven different strains of T.cruzi. The 
number of bugs of all nine species, used in xenodiagnosis of six guinea-pigs infected with the same strain was $486(54 \times 9)$. The total number of specimens of all nine species fed on all seven groups of guinea-pigs (six per group), each infected with a different strain of T.cruzi was 3402 (486 x 7).

Since bugs were exposed to the infection on days when parasitemia in hosts had reached its peak, xenodiagnosis in animals harboring "Berenice", "Y", "FL", "CL", "Colombiana", "Gávea" and "São Felipe" was done with 54 bugs derived from each of the nine vector species on days: $23,25,27,29,36$, 39 and 41 respectively, following inoculation of animals. Only 2016 of the 3402 bugs fed on the infected animals were utilized in these experiments because the original plan, of parasite determination in 48 specimens of each species, turned out to be tedious, time consuming and unmanageable under our laboratory conditions. Consequently only 32 bugs per species were examined as seen in Tables 1 and 2.

Bugs well engorged on the seven groups of six guinea-pigs each, representing one of the studied strains, were pooled in glass cylinders $(16 \times 22 \mathrm{~cm})$ covered with cheese-cloth and fastened with elastic bands, thus forming stocks of bugs harboring infections with different T.cruzi strains, utilized in this and other studies. Maintenance, feeding regime at biweekly intervals, the technique of bug examination and the scheme of representing results for analysis were essentially those described by Perlowagora-Szumlewicz \& Müller ${ }^{16}$ in 1987.

\section{RESULTS}

Both parameters, infectivity of vectors and parasite density within the vector, seemed commited to proceeding toward the choice of an experimental insect model for xenodiagnosis. Consequently, attention has been directed to the prevalence of infection, as measured by the proportion of bugs from any vector species, found positive upon feeding on guinea-pigs infected by the same parasite strain, as shown by the horizontal columns of Table 1 . The reactions of the vector species infected with different parasite strains are shown in the vertical columns of the Table 1 .

The intensity of infection, as measured by the proportion of parasites in 50 microscopic fields and the prevalence of heavy infections, as measured by the proportion of positive bugs with parasite counts $\geqslant 11$ in 50 fields, are summarized in Table 2 . The reasons for centering our attention on specimens with heavy infections had been described in detail in our recent paper ${ }^{16}$.

From the analysis of overalls seen in Table 1, it is obvious that although feeding of bugs from any of the studied species, on hosts infected with any of the seven parasite strains, evoke a positive reaction, diversity of results, expressed by varying proportions of infected bugs, are occuring invariably.

The lowest proportions of infected bugs were found among the domiciliated T.dimidiata ranging from $28.1 \%$ to $62.5 \%$ and $T$.infestans, varying from $46.9 \%$ to $84.4 \%$. The intermediate rates were displayed by R.prolixus, ranging from $71.9 \%$ to $100 \%$ and by T.brasiliensis, varying from $71.9 \%$ to $96.9 \%$.

The wild T.rubrovaria and R.neglectus, the essentially sylvatic $T$.sordida, $T$.pseudomaculata and P.megistus demonstrated from $90 \%$ (Addendum) to $100 \%$ of positives upon feeding on animals infected with all T.cruzi strains.

On the assumption that the use as xenodiagnostic agents bugs in which parasite densities are high, decrease the number of false negative cases and, on the contrary, when parasite yields are low, xenodiagnosis will fail to detect positives, overalls shown in Table 2 are based on the proportion of positives with heavy infections, as shown by parasite counts $\geqslant 11$ in 50 microscopic fields. This latter ranges; from $13 \%$ to $74.2 \%$ in the domiciliated $R$.prolixus fed on hosts with infections by different $T$.cruzi strains while in its congener, the wild R.neglectus, the proportion of bugs with heavy infections, produced by the same parasite strains, varied from $75 \%$ to $100 \%$.

As for the remaining vector species, Table 2 point to the existence of a close correlation between prevalence of infection, seen in Table 1 and intensity of infection shown in Table 2 , in that species, like R.neglectus, P.megistus, T.sordida,T.pseudomaculata, with infection rates varying from $90 \%$ (Addendun) to $100 \%$, also exhibit large proportions of bugs harboring heavy infections, ranging from $75 \%$ to $96.9 \%$. Only on rare occasions this has been found to be somewhat lower, as it is exemplified by T.rubrovaria. While prevalence of infection among bugs of T.rubrovaria was found to be invariably $100 \%$. The rates of positives harboring heavy infections varied from $65.6 \%$ to $90.6 \%$ (Table 2). The proportion of P.megistus carrying haevy infections is not $66.7 \%$ as seen in Table 2 but $83.5 \%$ as shown in Addendum. 


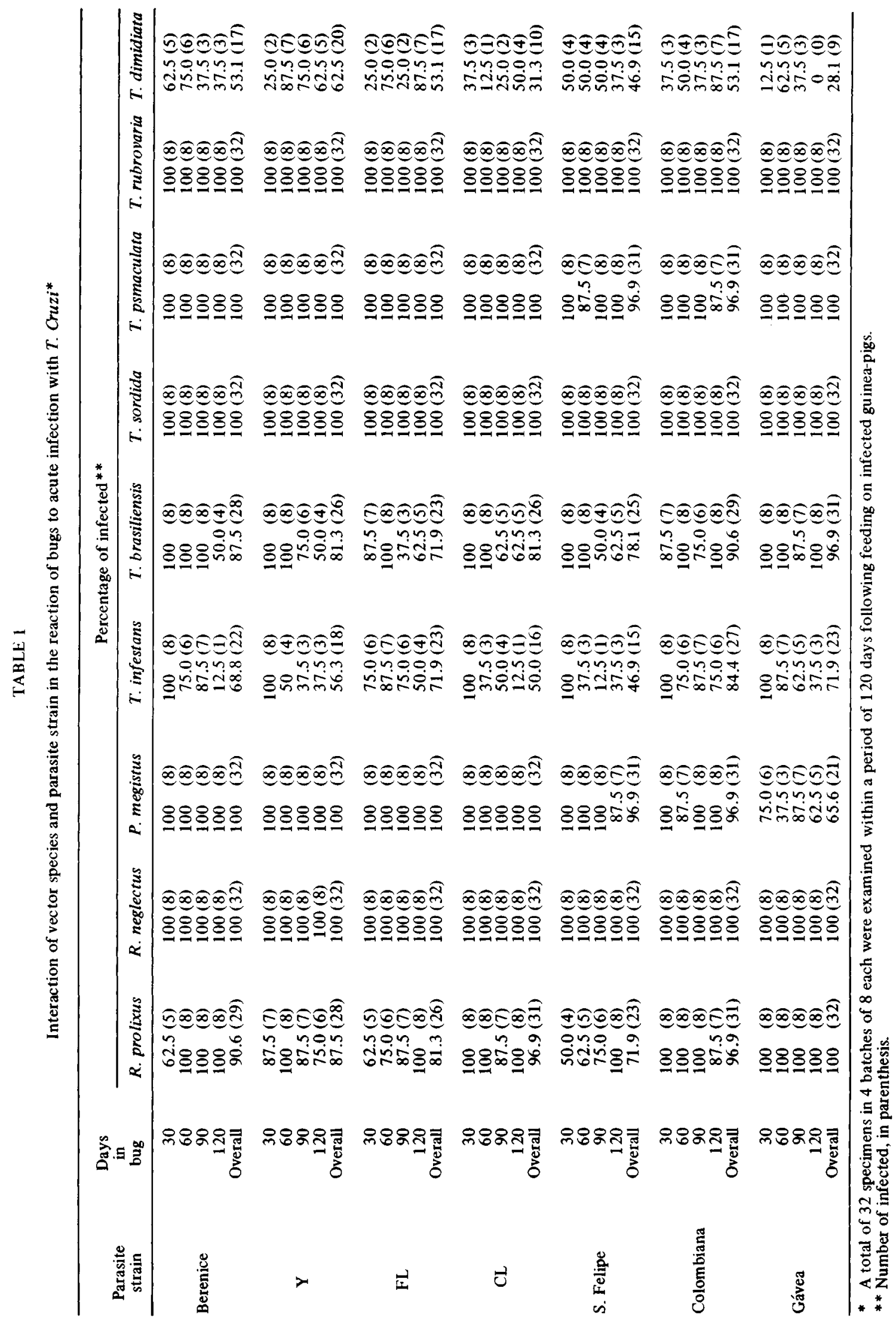




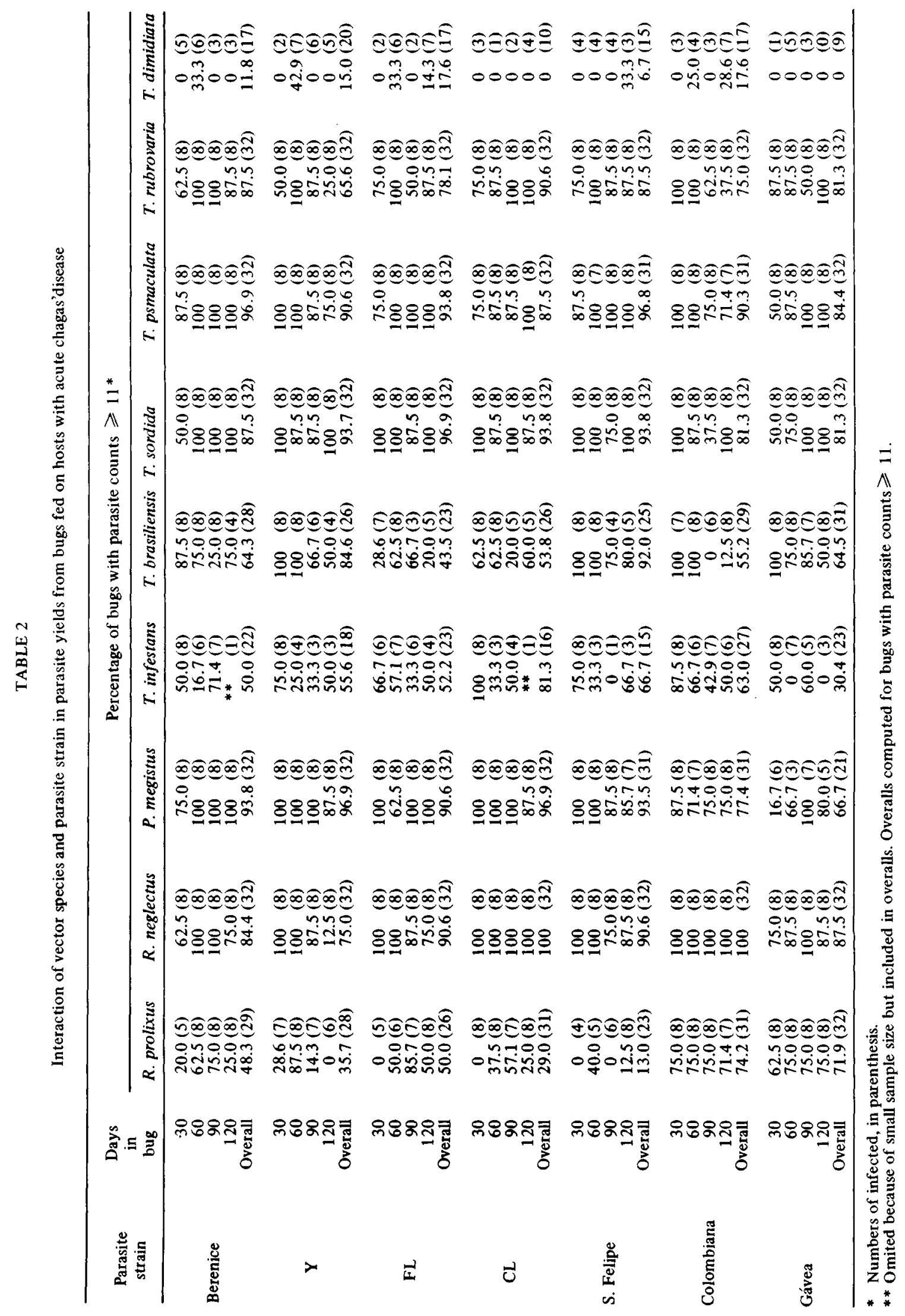


The poorest reaction to infection with the different $T$.cruzi strains had been registered in $T$.dimidiata, T.infectans and R.prolixus; the proportions of positive bugs with heavy infections varying from $0.0 \%$ to $17.6 \%$, from $30.4 \%$ to $81.3 \%$ and from $13 \%$ to $74.2 \%$ respectively (Table 2 ).

\section{DISCUSSION AND RECOMENDATIONS}

The reaction of nine vector species of Chagas'disease to infection by seven different strains of T.cruzi are examined and compared. The analysis of results makes it clear that the most important criterion for identifying a successful xenodiagnostic agent is its ability to establish and maintain the infection in high proportions of its population. Based on this vector species could be divided into two distinct groups which differ in their responsiveness to infections by the seven different T.cruzi strains. While the lowest proportion of positive bugs was found to be; $28.1 \%$ in T.dimidiata, $46.9 \%$ in T.infestans and $71.9 \%$ in R.prolixus, it has been invariably high, ranging from $90 \%$ (Addendum) to $100 \%$ in the species of T.sordida, T.pseudomaculata, T.rubrovaria, P.megitus and R.neglectus. We were surprised to find that $R$.prolixus was almost as effective as T.brasiliensis. It failed, however, to develop infections as heavy as found in the latter. The percentage of bugs with parasite counts $\geqslant 11$ ranged from $13 \%$ to $74.2 \%$ in prolixus while it varied from $43.5 \%$ to $92 \%$ in brasiliensis (Table 2).

No differences were observed in vector species responsiveness to infection by different T.cruzi strains, attributable to greater susceptibility of indigenous vector species of their own geographical area. This is well exemplified, on one hand, by the poor responsiveness of T.infestans and, on the other hand, by the excellent reaction of R.neglectus to the $\mathrm{Y}$ strain. Both species, as well as the parasite, derived from the State of São Paulo. Further support for this concept is provided by the strikingly good and uniform reactions of vector species derived from diverse and distant geographical areas like, neglectus, megistus, sordida, pseudomaculata and rubrovaria to Berenice isolated in "Belo Horizonte" from the first human case of Chagas'disease, or to FL isolated from naturaly infected bugs collected in "Rio Grande do Sul" (Table 1).

The functional role of the vector biotope in its reaction to infection was not elucidated. However, it has been observed to be constant and its importance could only be speculated upon sofar. For example, the poor reaction of the domiciliated bug to infection by $T . c r u z i$ could result from metabolic alterations while resident in domestic environments. The intermediate reaction observed in $R$.prolixus might be explained by the fact that it has been found to live in sylvatic and domestic environments. The vigorous and uniform reaction of sylvatic vectors to infection by all seven $T$.cruzi strains could suggest that the latter find a satisfactory environment in all of these vectors which in some sense should be similar. It also seems likely that the invertebrate hosts which are particularly efficient responders to the infection by one strain will also react well to infections by other strains of the same species.

The characterization of $T$.cruzi strains by the electrophoretic mobility of their isoenzymes enables us to classify $T$. cruzi strains into three principal zymodems that are capable to subdivide due to a variation ocurring within each, as described in 1986 by Miles \& Cibulskis ${ }^{10}$. Understandably, we have feared that there might arise a need to use different vector species as xenodiagnostic agents in order to detect infections by different T.cruzi strains. This would be a major drawback for the test which is per si laborious and requires large colonies of bugs. Also, doubt would be cast on the proposed general role of xenodiagnosis to uncover infections by T.cruzi. However, this was not the case. As based on the analysis of data referred to the sylvatic vector species seen in Table 1, it seems safe to say that our initial doubts about the validity of using the same xenodiagnostic agent to detect acute infection by different T.cruzi strains, have been minimized, thus relegating the vector species specificity to a minor role, in the choice of a xenodiagnostic agent among several good candidates. However in areas where the geographical distribution of the pathogenic $T$.cruzi overlaps with the non pathogenic T.rangeli, there might be a demand for a determined xenodiagnostic agent like, for example, R.neglectus (as observed in the laboratory) or D.maximus (as reported by Alvarenga \& Bronfen', 1984), in which the parasite differenciation, particularly the transition of epimastigotes to metacyclic trypomastigotes, is fast and voluminous, thus allowing a rapid distinction of the two different metatrypanosomes on the basis of the morphological aspect of their kinetoplasts.

The practical significance of findings that had emerged from the experiments described will not be evident until it is known whether those are also supported by the results from 
xenodiagnosis of chronic infections with the same seven strains of T.cruzi*. However, the task of answering the provocative question by Marsden ${ }^{8}$ why we are "still searching for a suitable xenodiagnostic agent without trying D.maximus", could not have been more timely, nor could our comments have been more appropriate.

As much as we would have desired to include D. maximus in our studies, we couldn't because we represent one of the "several laboratories that have had difficulty in rearing a colony of D.maximus for xenodiagnosis", although we have been quite successful in rearing colonies of 11 vector species since 1970 , under ambient conditions at a temperature varying from $25^{\circ}$ to $28^{\circ} \mathrm{C}$ and humidity ranging from $70 \%$ to $80 \%$. This experience stimulated us to continue the search for good xenodiagnostic agents because, as we pointed out in our recent paper ${ }^{16}$, some vector species which are suitable to be used in xenodiagnosis may not be conveniently produced by conventional laboratory means.

We also expressed surprise ${ }^{16}$ that the various groups of investigators in Brasilia, have been continously comparing two xenodiagnostic agents, the wild D.maximus with the domiciliated T.infestans, without trying P.megistus or another local sylvatic vector.

The genuine enthusiasm for D.maximus, as a potential xenodiagnostic agent, have been linked by many to its large size, indicating its ability to imbibe great quantities of infected blood. In 1978, Minter et al ${ }^{11}$. stated that the first instar P.megistus, used as an agent in revealing chronic human infections, performed as well as the much larger fifth instar $R$.prolixus, thus relegating body size to a minor role which effects are only apparent in exceptional circumstances, like in reactions to infections of different stages of the same vector, or among individuals of the same insect sample. This has been confirmed by us 15,16 in 1982, 1987 and in this report as shown in Table 1.

The observation that the wild D.maximus from México responded slightly better to the infection by the Brazilian strain of T.cruzi, than the Brazilian domiciliated T.infestans did as reported by Barreto et $\mathrm{al}^{2}$., conflicts with the general notion that indigenous vectors respond better to the infection by parasites of their own geographical area on one hand and on the other, it gives support to our hypothesis, linking prevalence, intensity and persistance of infection to the type of biotope the vector inhabits. However, scattered resistance to the role of mutual adaptation of vector parasite systems in vector infectivity remains. Alvarenga \& Bronfen ${ }^{1}$, when analyzing the diversity of infectivity rates by $\mathrm{Y}$ strain in T.infestans (67\%), D.maximus $(96 \%)$ and P.megistus $(98 \%)$, say that the environment of this latter favours the establishment and the persistance of the infection because it derives from the State of S. Paulo, where the Y strain had been isolated. This, however, is not convincing because P.megistus is an intruder in the area and at most is in process of adaptation to human homes, maintained under control following insecticidal elimination of T.infestans, as described by Barreto ${ }^{4}$ and Forattinis, while $T$. infestans has been there, probably since urbanization of the State started.

Implicit in the Editorial by Marsden ${ }^{8}$ is the statement that "first instar D. maximus proved as effective as third instar $T$. infestans in isolating $T$. cruzi from patients with chronic infections and rearing costs are reduced as a result". This raised the immediate question, whether an insect that is as efficient as $T$. infestans, which has been repeatedly found to be one of the poorest responders to infection by $T$. cruzi $\mathrm{Y}$ strain ${ }^{15,16}$ merits to be singled out as an adequate xenodiagnostic agent.

Among the major virtues of $D$. maximus, as cited by Marsden ${ }^{9}$ are: 1 - its ability to function as a xenodiagnostic agent in the first stage of development, thus reducing rearing costs; $2-$ its resistance to starvation, as shown by the ability to live up to 4 months without food and $3-$ its agressive feeding habits.

As printed it conveys the misleading message that the time taken by this insect to reach the first developmental stage, recommended to use in xenodiagnosis, takes only 37 days. Marsden? failed to include the lenght of the preoviposition period described by Barreto et al. ${ }^{2}$, which is species specific and affects substantially the developmental time of individual stages, as seen in the Table 3.

Marsden ${ }^{7}$ also overrated the two other characteristics of the insect described by Barreto et al. ${ }^{2}$ : the mean longevity of unfed third instar $T$. infestans was more than double of that registered for the first instar $D$. maximus. Also the third stage $T$. infestans and $P$. megistus have been found to be slightly more agressive feeders than the first stage $D$. maximus (Table 3).

* Unpublished data. 


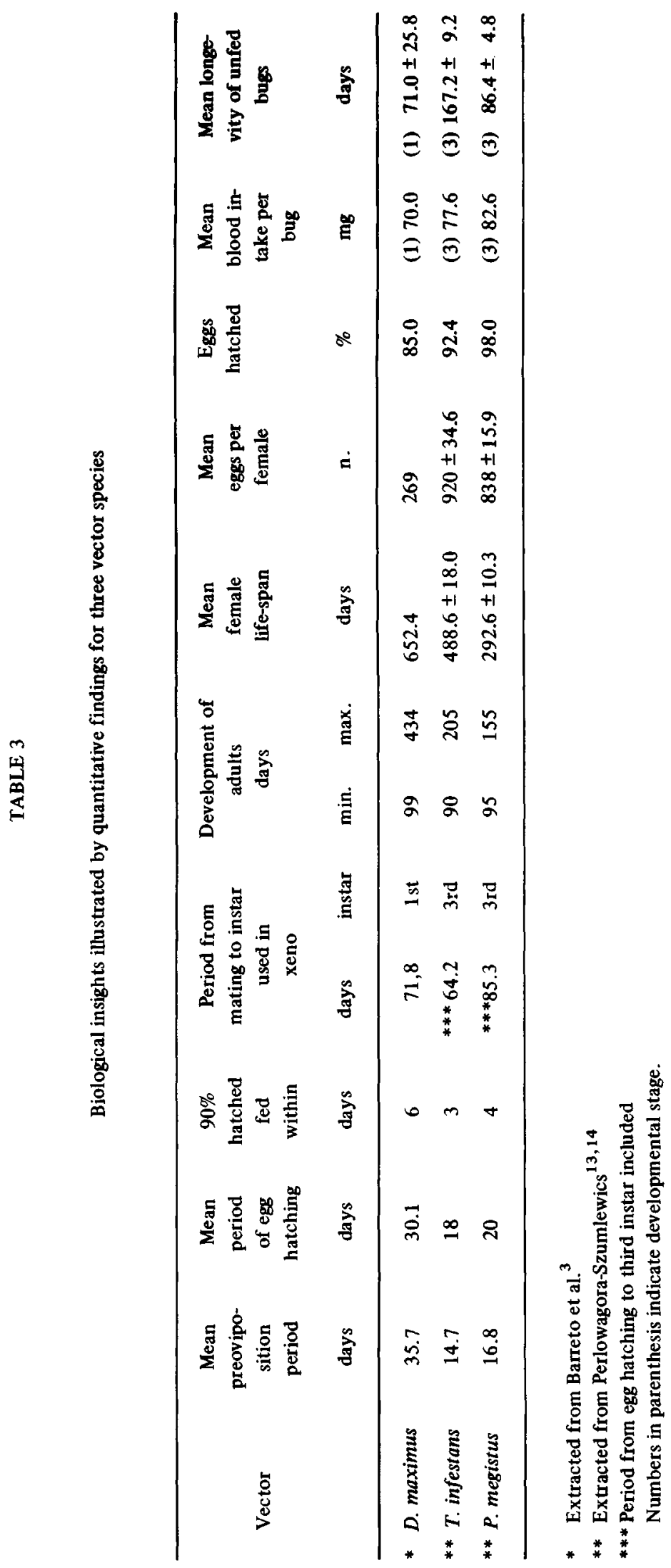


In essence, comparison of figures shown in the Appendix suggests that the benefits gained by using first instar $D$. maximus instead of third stage $T$. infestans are rather small. As for the reduced rearing costs it is difficult to speculate upon because it has not been compared with those of the third stage $T$. infestans.

When quoting the costs of ten American cents per egg that leads to four dollars for each xenodiagnostic test with 40 first stage $D$. maximus, one should remember that this might be a relatively high price in the underdeveloped countries where Chagas' disease is endemic in nature.

However, all that has been said is not to undermine the investigation that discovered an insect in which $T$. cruzi undergoes an exceptional high rate of epimastigotes-to-metacyclic trypomastigotes transformation, as described in 1984 by Alvarenga \& Bronfen'. Although this finding has not proved particularly useful in the choice of xenodiagnostic agent candidates, it is of major importance to investigators involved in classification of $T$. cruzi strains on the basis of isoenzyme profiles reported by Miles \& Cibulskis ${ }^{10}$, in the analysis of infection of bugs with single-cell-isolate clones of $T$. cruzi, described by Garcia \& Dvorak ${ }^{7}$ and also for the characterization of parasites on the genotype level at least until new techniques that would not require parasite population amplification are developed, as stated in 1986 by Morel et al ${ }^{12}$. Consequently this insect will have more enthusiastic backing among investigators mentioned above but, there will be some scepticism for using it in field surveys. What really worries us is primarily, that the insect may be safe to use in experimental studies in the laboratory or in the hospital, but getting it from the laboratory to endemic areas, where xenodiagnosis is being performed on a large scale, utilizing thousands of specimens, is not risk free. This may serve as a reminder that involuntary infestation followed by colonization of a new voracious and large insect, which exhibit high rates of epimastigotes to metacyclic trypomastigotes conversion, will be an additional menace to the population. That "it is" only "slightly less susceptible to insecticide activity than $T$. infestans", as mentioned by Marsden ${ }^{8}$, is of no comfort.

Secondarily, Marsden ${ }^{8}$ conveys the message to stop searching for a suitable xenodiagnostic agent, because such is already on hand. It is $D$. maximus, the vefficacy of which, in incubating $T$. cruzi (Y and CL strains so far), has been demonstrated by Alvarenga and Bronfen ${ }^{1}$.

The article ${ }^{1}$ is perhaps the most serious contribution to the discouragement of the interest in further screening of vectors for xenodiagnostic purposes. What if $D$. maximus wind up inaccessible because of rearing difficulties, as we have experienced years ago, and there are no funds to install temperature and humidity regulators? One should keep in mind that until new techniques which would not require large colonies of bugs, nor the exams of up to 40 bugs per infected hosts have been developed, we will have to search for more efficient xenodiagnostic agents than $D$. maximus.

As for $P$. megistus, which has been found by Perlowagora-Szumlewicz \& Muller ${ }^{16}$ to exhibit over $90 \%$ of positives, of which over $60 \%$ harbor either dense or very dense parasite populations upon feeding on animals with chronic infections by $\mathrm{Y}$ strain of $T$. cruzi, our opinion is that at present it deserves top priority as a xenodiagnostic agent. This bug has also other advantages; it is available in many parts of Brazil, easy to breed under changing ambient conditions, fast in development, slow in locomotion (an attractive feature in managing it) and low in mortalities. While only $5 \%$ of $P$. megistus used in preliminary field surveys died, around $20 \%$ of $D$. maximus were found dead in similar experiments by Marsden et al' . 
PERLOWAGORA-SZUMLEWICZ, A. et al. Estudos em busca de um inseto modelo experimental para xenodiagnóstico em hospedeiros com doença de Chagas. 3 - A interação entre a espécie vetora e a cepa do parasito na reação do vetor à infecção com Trypanosoma cruzi. Rev. Saúde públ., S. Paulo, 22:390-400, 1988.

RESUMO: É examinada e comparada a reação de nove espécies vetoras da doença de Chagas à infecção, por sete diferentes cepas do T.cruzi (Berenice, Y, FL, CL, São Felipe, Colombiana e Gávea). Com base na habilidade em estabelecer e manter a infecção, as especies vetoras podem ser divididas em dois grupos distintos, que diferem em suas reaçōes à infecção aguda por T.cruzi. Enquanto a proporção de insetos positivos foi baixa em domiciliados (Triatoma infestans e Triatoma dimidiata), foi alta nos considerados completamente selvagens (Rhodnius neglectus e Triatoma rubrovaria), ao serem iniciadas suas colonizaçōes no laboratório, no início da década de 70, e nos essencialmente silvestres (Panstrongylus megistus, Triatoma sordida e Triatoma pseudomaculata). Admite-se que devido à exploração agropecuária e graças às campanhas de controle, os dois últimos grupos encontram mais freqüentemente condiçőes que lhes permitem maior convivência com o homem e animais domésticos. As proporçðes de positivos nas cinco últimas espécies acima citadas, cada qual infectada com uma das sete cepas do T.cruzi, quando somadas ( 34 "Overalls") variam de $90 \%$ a $100 \%$, com exceção de $65,6 \%$ encontrada em P.megistus infectado com a cepa Gávea. A posição intermediária está sendo ocupada por Triatoma brasiliensis e Rhodnius prolixus, o último alternando entre biótipo natural e artificial. Achado relevante foi a uniformidade de reaçסes dos vetores silvestres às infecçðes com, praticamente, todas as cepas do T.cruzi, sugerindo que o fator ou fatores responsáveis pela reação do P.megistus à infecção pela cepa $Y$ também operam nas reaçðes desta espécie com as restantes cepas, embora, várias destas tenham sido bioquimicamente diferentes entre si. A comparação dos dados aqui apresentados com os relatados por outros investigadores, forma a base da discussão sobre a superioridade de uso do D.maximus como agente no xenodiagnóstico.

UNITERMOS: Tripanossomose Sul-Americana, diagnóstico. Insetos vetores, parasitologia. Relações hospedeiro-parasita. Triatoma, parasitologia. Panstrongylus, parasitologia. Rhodnius, parasitologia. Trypanosoma cruzi.

\section{REFERENCES}

1. ALVARENGA, N.J. \& BRONFEN, E. Integração do Trypanosoma cruzi com diferentes vetores: uso para o xenodiagnóstico. Rev. Soc. bras. Med. trop., 17:145-9, 1984.

2 BARRETO, A.C.; MARSDEN, P.D.; CUBA, C.C.; ALVARENGA, N.J. Estudo preliminar de Dipetalogaster maximus (Uhler, 1894) (Triatominae) na técnica do xenodiagnóstico em forma crônica da Doença de Chagas. Rev. Inst. Med. trop. S. Paulo, 20:183-9, 1978.

3. BARRETO, A.C.; PRATA, A.R.; MARSDEN, P.D.; CUBA, C.C.; TRIGUEIRA, C.P. Aspectos biológicos e criação em massa de Dipetalogaster maximus (Uhler, 1894) (Triatominae). Rev. Inst. Med. trop. S. Paulo, 23:18-27, 1981.

4. BARRETO, M.P. Possible role of wild mammals and triatomines in the transmission of Trypanosome cruzi to man. In: International Symposium on New Approaches in American Trypanosomiasis Research, Belo Horizonte, MG, 1975. Proceedings. Washington, D.C., Pan American Health Organization, 1976. p. 307-16 (PAHO - Scientific Publication, 318).

5. FORATTINI, O.P.; ROCHA E SILVA, E.O.; RABELLO, E.X.; REHDER DE ANDRADE, J.C.; CORREIA RODRIGUES, V.L.C. Aspectos ecológicos da tripanossomíase americana. XIII - Potencial enzoótico doméstico em área de ocorrência de Panstrongylus megistus sob vigilâncial epidemiológica. Rev. Saúde públ., S. Paulo, 12:417-24, 1978.

6. FORATTINI, O.P.; FERREIRA, O.A.; ROCHA E SILVA, E.O.; RABELLO, E.X. Aspectos ecológicos da tripanossomíase americana. XIV - Persistência e potencial de domiciliação de populações triatomínicas silvestres em região de intensa atividade agropecuária. Rev. Saúde públ., S. Paulo, 13:123-46, 1979.
7. GARCIA, E.S. \& DVORAK, J.A. Growth and development of two Trypanosoma cruzi clones in the arthropod Dipetalogaster maximus. Amer. J. trop. Med. Hyg., 31:259-62, 1982.

8. MARSDEN, P.D. Dipetalogaster maxima ou $D$. maximus como agente no xenodiagnóstico [Editorial]. Rev. Soc. bras. Med. trop., 19:205-7, 1986.

9. MARSDEN, P.D.; BARRETO, A.C.; CUBA, C.C.; GAMA, M.B.; ACKERS, J. Improvements in routine xenodiagnosis with first instar Dipetalogaster maximus (Uhler 1894) (Triatominae). Amer. J. trop. Med. Hyg., 28:649-52, 1979.

10. MILES, M.A. \& CIBULSKIS, R.E. Zymodeme characterization of Trypanosoma cruzi. Parasit. Today, 2:94-7, 1986.

11. MINTER, D.M.; MINTER-GOEDBLOED, E.; MARSHALL, T.F. de C. Comparative xenodiagnosis with three triatomine species of different hosts with natural and experimental chronic infections with Trypanosoma (Schizotrypanum) cruzi. Trans. roy. Soc. trop. Med. Hyg., 72:84-91, 1978.

12. MOREL, C.M.; DEANE, M.P.; GONÇALVES, A. M. The complexity of Trypanosoma cruzi populations reveald by Schizodeme analysis. Parasit. Today, 2:97-101, 1986.

13. PERLOWAGORA-SZUMLEWICZ, A. Species and stage interaction in the feeding behaviour of vectors of Chagas' disease (the importance of determinants in planning for greater efficacy and standardization of xenodiagnostic procedures). Rev. Inst. trop. S. Paulo, 15:139-50, 1973.

14. PERLOWAGORA-SZUMLEWICZ, A. Laboratory colonies of triatominae. Biology and population dynamics. In: International Symposium on New Approaches in American Trypanosomiasis Research, Belo Horizonte, MG, 1975. Proceedings. Washing- 
ton, D.C., Pan American Health Organization, 1976. p. 63-82. (PAHO - Scientific Publication, 318).

15. PERLOWAGORA-SZUMLEWICZ, A. \& MULLER, C.A. Studies in search of a suitable experimental insect model for xenodiagnosis of hosts with Chagas' disease. 1 - Comparative xenodiagnosis with nine triatominae species of animals with acute infections by Trypanosoma cruzi. Mem. Inst. Oswaldo Cruz, Rio de Janeiro, 77:37-53, 1982.

16. PERLOWAGORA-SZUMLEWICZ, A. \& MULLER, C.A. Studies in search of a suitable experimental insect model for xenodiagnosis of hosts with Chagas' disease. 2 - Attempts to upgrade the efficiency and reliability of xenodiagnosis in chronic Chagas' disease. Mem. Inst. Oswaldo Cruz, Rio de Janeiro, 82:259-72, 1987.

17. SILVEIRA, A.C.; RAMOS FEITOSA, V.; BORGES, R. Distribuição de triatomíneos capturados no ambiente domiciliar, no período 1975/83, Brasil. Rev. bras. Malar., 36:15-312, 1984.

Received in $28 / 12 / 19877$

Reviewed in 19/5/1988

Accepted in 26/5/1988

\section{ADDENDUM}

We have been long advocating greater emphasis on $P$. megistus as the xenodiagnostic agent of choice. Nonetheless support has also been given to other promissing candidates singled on in screening of sylvatic vectors.

Events herein described did not occur quite in the order we had envisaged. In place of the long established superiority of $P$. megistus over the other sylvatic candidates the contrary occured. This has been well exemplified by the relatively low infectivity rate of $65.5 \%$ (Table 1 ) and the low proportion of $66.7 \%$ of positives with heavy infection (Table 2) exhibited by this bug fed on hosts harboring "Gávea" strain of $T$. cruzi.

However, this observation did not reverse our previous position toward this bug described in $1982^{15}$ and $1987^{16}$. On the contrary, it has been deepening our belief in linking the poor results obtained with a lack of nutrients in the bug, although our imagination vacilated between this latter and some pecularities of the little known "Gávea" strain of $T$. cruzi. The former has been first attacked through an experiment based on the reasonable convincing evidence of the important pari played by additional feeds given to bugs from xenodiagnosis on the population dynamics of the parasite, as described in $1987^{16}$.

A group of fourth instar nymphs starved during a period of 2-3 weeks, since transition from the proceeding stage, was fed once on guineapigs harboring "Gávea" parasite. The: well engorgep specimens were divided in two iquall subgroups. One was fed on chicken blood at biweekly' intervals following infection, the second was kept under: starvation for a period of 90 days, during which randomly, chosen 10 specimens from each group were examined and the: proportion of positives as well as the rate of those with heavy, infections were recorded.

Results presented in the attached Table have been more impressive than we have imagined. The infectivity rates in those receiving supplementary feeds rose to $90 \%$ and the: proportion of specimens with heavy infections reached the: level of $83.3 \%$, while the starved bugs exhibited $62.5 \%$ of: positive specimens and $64 \%$ of bugs with heavy infections. The latter two values have a provocative similarity with the: values of $65.5 \%$ and $66.7 \%$ found in $P$. megistus fed on । hosts with "Gávea" strain shown in Tables 1,2 .

We do hope that the comparison of the unchanged data seen in Tables 1, 2 with those described in the Addendum । may serve as a reminder that when examination of bugs from xenodiagnosis is being postponed for periods longer than 15; days supplementary feeds on normal blood seems to be: mandatory.

Illustrating changes in infectivity rates and parasite densities in $P$. megistus receiving supplementary feeds upon xenodiagnosis.

\begin{tabular}{ccccc}
\hline Infection in bugs & \multicolumn{2}{c}{ Bugs receiving supplementary feeds } & \multicolumn{2}{c}{ Bugs kept under starvation } \\
Days & $\mathrm{N}$. & $\%$ & $\mathrm{~N}$. & $\%$ \\
\hline & \multicolumn{3}{c}{ Infected bugs } \\
30 & 9 & 90 & 3 & 30 \\
45 & 8 & 80 & 8 & 80 \\
60 & 9 & 90 & 7 & 70 \\
90 & 10 & 100 & 7 & 62.5 \\
Overall & 36 & 90 & 25 & \\
& & & \\
& & & 2 & 66.7 \\
30 & Bugs with parasite conts $\geqslant 11 / 50$ microscopic fields & 62.5 \\
45 & 5 & 55.6 & 5 & 71.4 \\
60 & 7 & 87.5 & 5 & 57.2 \\
90 & 8 & 88.9 & 4 & 64.0 \\
Overall & 10 & 100 & 16 & \\
\hline
\end{tabular}

